\begin{tabular}{|c|c|c|}
\hline & International Journal of Current Research in \\
Biosciences and Plant Biology \\
EXCELLENT \\
PUBLISHERS
\end{tabular}

Original Research Article

doi: $\underline{\text { https://doi.org/10.20546/ijcrbp.2018.505.010 }}$

\title{
Presence of Trees under Agroforestry Systems along Altitude in Gangotri Valley of Garhwal Himalaya, India
}

\author{
Arvind Bijalwan* \\ Area of Technical Forestry, Indian Institute of Forest management (IIFM), Bhopal- 462003 , \\ Madhya Pradesh, India \\ ${ }^{*}$ Corresponding author.
}

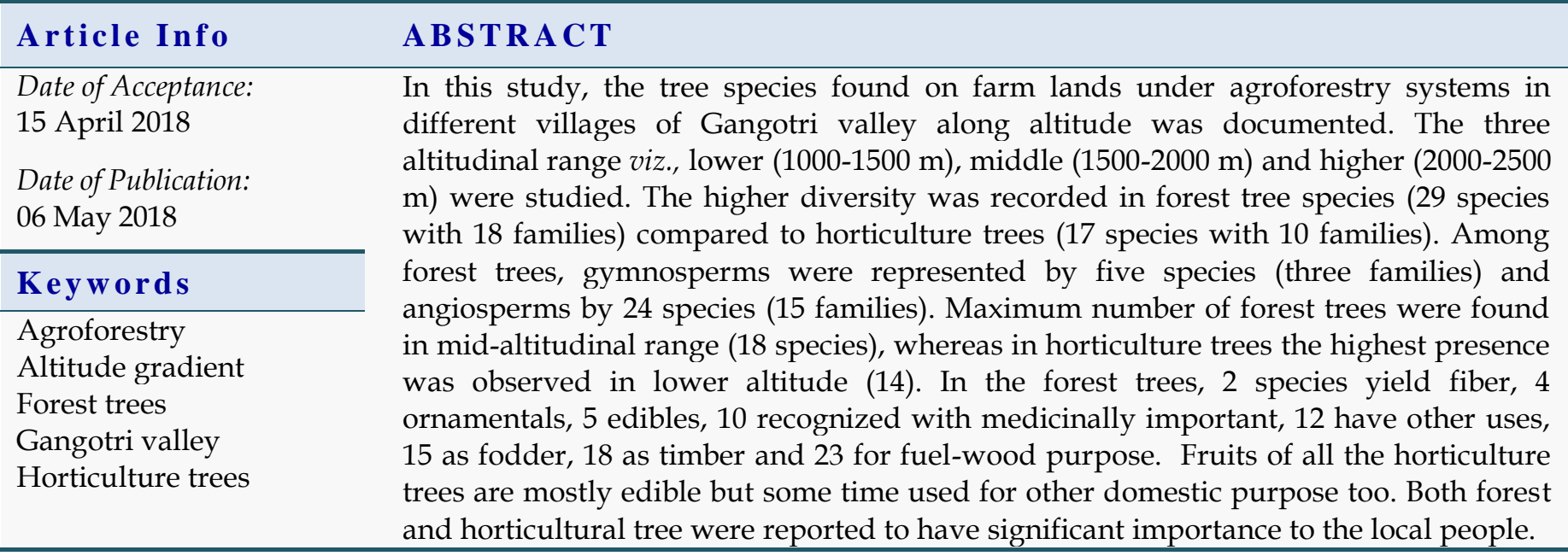

\section{Introduction}

After food crop, the second place comes for trees because trees are also source of innumerable services. Trees are also a part of diverse agroforestry systems and traditional agroforestry systems have been practiced in Garhwal region of Uttarakhand since early period (Iqbal et al., 2014; Gupta and Arora, 2015). Agroforestry is an effective practice to improve farmer livelihood and simultaneously increasing the green cover of the area. The present study was an attempt to enlist the different forest and horticulture tree species growing on agriculture field under agroforestry.

\section{Materials and methods}

The study was conducted along altitudinal changes in Gangotri valley (Uttarkashi distict) of Garhwal Himalaya, India. Six villages namely, Siror (1394 $\mathrm{m})$ and Netala $(1459 \mathrm{~m})$ in the lower altitude, Silla 
$(1765 \mathrm{~m})$ and Malla $(1837 \mathrm{~m})$ in middle and Jhalagaon (2213 m) and Sukkhi $(2500 \mathrm{~m})$ in higher altitude were selected according to varying altitudinal ranges (lower altitude 1000-1500m, middle altitude 1500-2000 $\mathrm{m}$ and higher altitude 2000-2500 m). Random quadrats were laid in different areas according to species area curve during 2016-2017.

\section{Results and discussion}

In the present study, 29 species of forest trees were observed as agroforestry tree species comprising 18 families, out of which five species were of gymnosperms (three families) and 24 species (15 families) were of angiosperms (Table 1). In horticulture trees, there were 17 species (10 families). Middle (18 species) altitude region showed highest number of forest tree species followed by lower (16) and higher (6) altitude, whereas, in horticulture trees, lower (14 species) altitude showed greatest species diversity followed by middle (8) and higher (5) altitude region (Table $2)$. Some forest tree species were restricted to particular altitude region, where middle ( 9 species) altitude shows greatest confinement trailed by lower (7) and higher (3) altitude region. Among horticultural trees, lower altitude depicted highest number of restricted species (9), whereas, middle and higher altitude showed no species restriction. Seven forest tree species were observed in both lower-middle altitude regions namely, Celtis australis, Grewia optiva, Jacaranda mimosifolia, Melia azedarach, Populus ciliata, Quercus leucotrichophora, Toona ciliata and only one (Pistacia integerrima) species in middle-higher altitude region (Table 1). One peculiar species was Cedrus deodara which was observed in lower and higher altitude region, but not in middle altitude region. The most widely distributed species was Pinus roxburghii, which was observed in all three altitude regions.

Table 1. Forest Trees under Agroforestry system along elevation.

\begin{tabular}{|c|c|c|c|c|c|}
\hline Family & Species & $\begin{array}{l}\text { Vernacular } \\
\text { name }\end{array}$ & English name & Uses & Elevation \\
\hline \multicolumn{6}{|l|}{ Gymnosperms } \\
\hline Cupressaceae & $\begin{array}{l}\text { Cupressus torulosa } \\
\text { D.Don. ex Lamb. }\end{array}$ & Surai & $\begin{array}{l}\text { Himalayan } \\
\text { Cypress }\end{array}$ & $\begin{array}{l}\text { Wood is used as fuel and highly } \\
\text { durable for timber }\end{array}$ & $\mathrm{L}$ \\
\hline \multirow{2}{*}{ Pinaceae } & $\begin{array}{l}\text { Pinus roxburghii } \\
\text { Sarg. }\end{array}$ & Chir & Chir-Pine & $\begin{array}{l}\text { Seeds are eaten, wood is used as fuel } \\
\text { and timber, turpentine obtained from } \\
\text { sapwood, Leaf Needles used to make } \\
\text { organic manure, surface roots contain } \\
\text { ecto-mycorrhizae thus prevents } \\
\text { leaching of phosphorous }\end{array}$ & $\mathrm{L}, \mathrm{M}, \mathrm{H}$ \\
\hline & $\begin{array}{l}\text { P. wallichiana A. B. } \\
\text { Jacks. }\end{array}$ & Kail & $\begin{array}{l}\text { Himalayan } \\
\text { Blue Pine }\end{array}$ & $\begin{array}{l}\text { Seeds are eaten, wood used as fuel } \\
\text { and timber, turpentine obtained from } \\
\text { sapwood, leaves used as animal } \\
\text { bedding, surface roots contain ecto- } \\
\text { mycorrhizae thus prevents leaching } \\
\text { of phosphorous }\end{array}$ & $\mathrm{H}$ \\
\hline Taxaceae & $\begin{array}{l}\text { Taxus wallichiana } \\
\text { Zucc. }\end{array}$ & Thuner & Himalayan yew & $\begin{array}{l}\text { Wood is used as fuel and incense, } \\
\text { wood has medicinal value }\end{array}$ & $\mathrm{H}$ \\
\hline
\end{tabular}




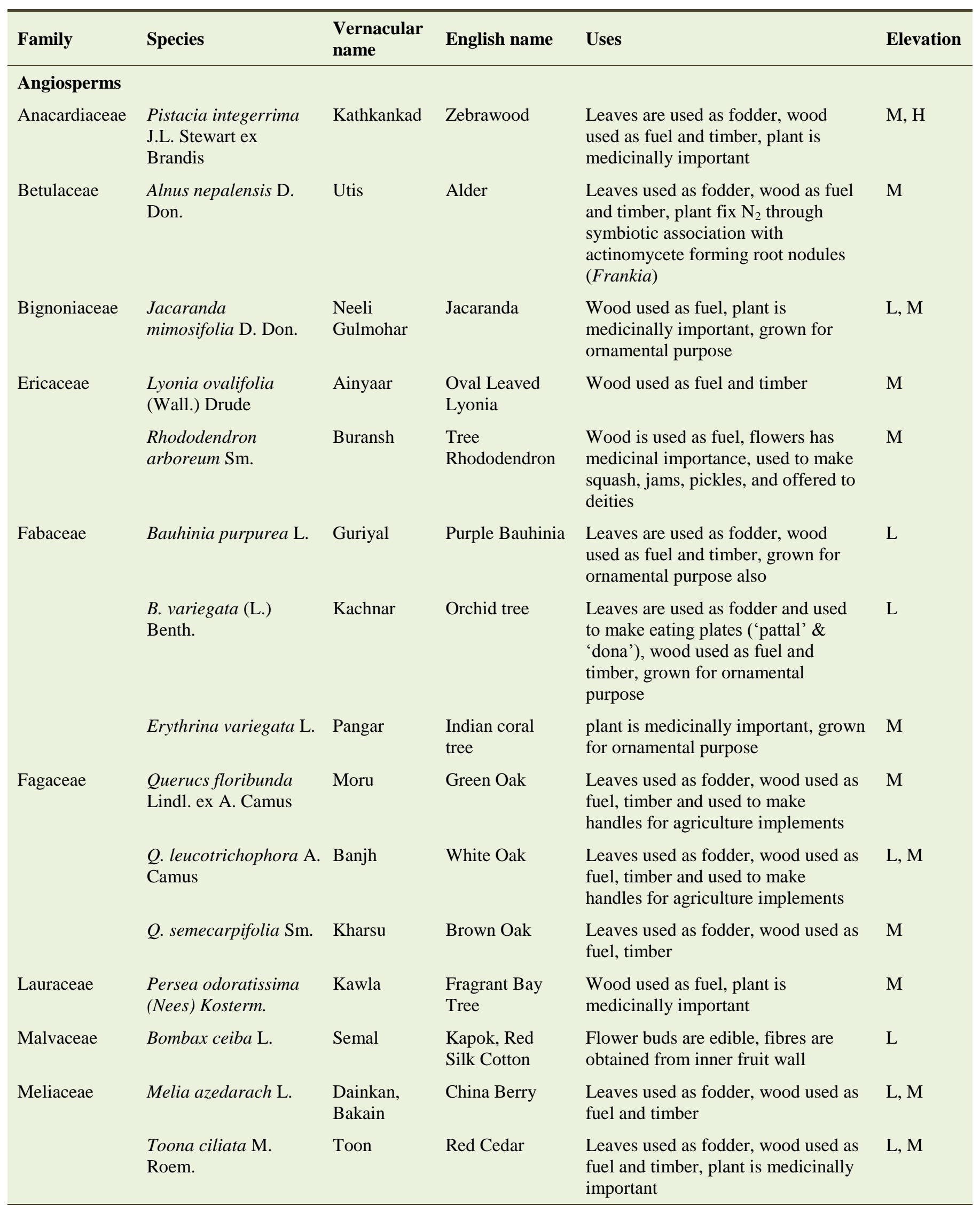




\begin{tabular}{|c|c|c|c|c|c|}
\hline Family & Species & $\begin{array}{l}\text { Vernacular } \\
\text { name }\end{array}$ & English name & Uses & Elevation \\
\hline \multirow[t]{2}{*}{ Moraceae } & F. palmata Forssk. & Bedu & $\begin{array}{l}\text { Wild } \\
\text { Himalayan Fig }\end{array}$ & Fruit is edible, leaves used as fodder & M \\
\hline & F. religiosa $\mathrm{L}$. & Peepal & Sacred Fig & $\begin{array}{l}\text { Fruit is edible, leaves used as fodder } \\
\text { and in religious ritual, wood used as } \\
\text { fuel }\end{array}$ & $\mathrm{L}$ \\
\hline Myrtaceae & Eucalyptus sp. & Neelgiri & Eucalypt & $\begin{array}{l}\text { Wood is used as fuel and timber, } \\
\text { plant is medicinally important }\end{array}$ & $\mathrm{L}$ \\
\hline \multirow[t]{2}{*}{ Salicaceae } & $\begin{array}{l}\text { Casearia tomentosa } \\
\text { Roxb. }\end{array}$ & Chhila & $\begin{array}{l}\text { Toothed Leaf } \\
\text { Chilla }\end{array}$ & Plant is medicinally important & M \\
\hline & $\begin{array}{l}\text { Populus ciliata Wall. } \\
\text { ex Royle }\end{array}$ & Van Peepal & $\begin{array}{l}\text { Himalayan } \\
\text { Poplar }\end{array}$ & $\begin{array}{l}\text { Leaves used as fodder, wood used as } \\
\text { fuel and timber }\end{array}$ & $\mathrm{L}, \mathrm{M}$ \\
\hline Sapindaceae & $\begin{array}{l}\text { Sapindus mukorossi } \\
\text { Gaertn }\end{array}$ & Reetha & $\begin{array}{l}\text { Indian } \\
\text { Soapberry }\end{array}$ & $\begin{array}{l}\text { Leaves used as fodder, wood used as } \\
\text { fuel, fruit pulp used as soap }\end{array}$ & $\mathrm{L}$ \\
\hline Tiliaceae & $\begin{array}{l}\text { Grewia optiva J. R. } \\
\text { Drumm. ex Burret }\end{array}$ & Bhimal & & $\begin{array}{l}\text { Leaves used as fodder, fibre obtained } \\
\text { from bark, wood used as fuel, timber, } \\
\text { used to make handles of agriculture } \\
\text { implements and as torchlight } \\
\text { ('Muchala'), bark used as hair wash }\end{array}$ & $\mathrm{L}, \mathrm{M}$ \\
\hline Ulmaceae & Celtis australis L. & Khadik & $\begin{array}{l}\text { European } \\
\text { Hackberry }\end{array}$ & $\begin{array}{l}\text { Leaves used as fodder, wood used as } \\
\text { fuel and timber }\end{array}$ & $\mathrm{L}, \mathrm{M}$ \\
\hline
\end{tabular}

Abbreviations: L - lower elevation (1000-1500 m, a.m.s.1.), M - middle elevation (1500-2000 m, a.m.s.1.), H - higher elevation (2000-2500 m, a.m.s.1.), m, a.m.s.l. - meters, above mean sea level

Among, horticulture trees, three species showed distribution in lower-middle altitude region viz., Citrus aurantium, $C$. sinensis and Ficus auriculata, three species in middle-higher region - Malus pumila, Prunus armeniaca and Pyrus communis while, only one species was observed in all the three altitudes - Prunus persica (Table 2).

In forest trees, 23 species yield fuel-wood, 18 timbers, 15 fodder, 12 have other uses, 10 have medicinal importance, five are edible, four are ornamental and two yield fiber. In the edible species, the economically important part is flower bud (1 species), fruit (2) and seeds (2). In the fiber yielding species, fibers are obtained from inside of fruit wall and bark. Other uses of forest tree species are: religious, used in juice and squash, as torchlight, turpentine source, as soap, in making eating plates and bowls and in making handles of agriculture equipments. In the horticulture species fruits are edible, among the forest tree species, three species were found in- Fabaceae, Fagaceae and Pinaceae, and two species were recorded in Ericaceae, Meliaceae, Moraceae, Salicaceae and Sapindaceae and rest of the families contained one species each.

Present study, recorded different forest and horticulture tree species found under different agroforestry systems in the Gangotri valley of Uttarkashi district of India along varying altitudinal ranges. The forest tree species showed greater species diversity than horticulture species that could be : a) forest trees have a naturalized 
presence over a long time, whereas, people started growing horticulture trees afterward for fruit purpose, b) the seeds of forest trees can use services of local seed dispersers or have winged seeds (e.g. Pinus, Cedrus) to disperse their seeds whereas, horticulture trees rely on human service for seed sowing or seedling/sapling plantation, c) forest trees are hardy and adapted to local climatic conditions, thus, they can better resist local environmental fluctuations, whereas, horticulture trees cannot resist climate extreme, and d) forest trees retained by the farmer are mostly multipurpose and supplement their daily domestic need.

Table 2. Horticulture trees under agroforestry system along elevation.

\begin{tabular}{|c|c|c|c|c|c|}
\hline Family & Species & $\begin{array}{l}\text { Vernacula } \\
\text { r name }\end{array}$ & $\begin{array}{l}\text { English } \\
\text { name }\end{array}$ & Uses & Elevation \\
\hline Anacardiaceae & Mangifera indica L. & Aam & Mango & $\begin{array}{l}\text { Fruit edible, wood used as fuel and } \\
\text { timber, plant is medicinally } \\
\text { important, leaves and wood used in } \\
\text { religious rituals }\end{array}$ & $\mathrm{L}$ \\
\hline Euphorbiaceae & Emblica officinalis L. & Amla & $\begin{array}{l}\text { Indian } \\
\text { Gooseberry }\end{array}$ & $\begin{array}{l}\text { Fruit edible, plant is medicinally } \\
\text { important, plant used in religious } \\
\text { rituals }\end{array}$ & $\mathrm{L}$ \\
\hline Juglandaceae & Juglans regiaL. & Akhrot & Walnut & $\begin{array}{l}\text { Fruit edible, wood used as fuel and } \\
\text { timber }\end{array}$ & $\mathrm{L}, \mathrm{M}, \mathrm{H}$ \\
\hline Lauraceae & $\begin{array}{l}\text { Cinnamomum tamala } \\
\text { (Buch.-Ham.) } \\
\text { T.Nees\&C.H.Eberm }\end{array}$ & Tejpatta & $\begin{array}{l}\text { Indian Bay } \\
\text { Leaf }\end{array}$ & $\begin{array}{l}\text { Leaves used as spice, plant is } \\
\text { medicinally important }\end{array}$ & $\mathrm{L}$ \\
\hline \multirow{3}{*}{ Moraceae } & Ficus glomerata Roxb. & Goolar & Cluster Fig & $\begin{array}{l}\text { Fruit edible, leaves used as fodder, } \\
\text { wood used as fuel and timber }\end{array}$ & $\mathrm{L}$ \\
\hline & Ficus palmata Forssk. & Bedu & $\begin{array}{l}\text { Wild } \\
\text { Himalayan } \\
\text { Fig }\end{array}$ & $\begin{array}{l}\text { Fruit edible, leaves used as fodder, } \\
\text { plant is medicinally important }\end{array}$ & $\mathrm{L}$ \\
\hline & Morus alba L. & Shetoot & $\begin{array}{l}\text { White } \\
\text { Mulberry }\end{array}$ & $\begin{array}{l}\text { Fruit edible, leaves used as fodder, } \\
\text { wood used as fuel }\end{array}$ & $\mathrm{L}$ \\
\hline Myrtaceae & Psidium guajava L. & Amrood & Guava & $\begin{array}{l}\text { Fruit edible, leaves used as fodder, } \\
\text { wood used as fuel, plant is } \\
\text { medicinally important }\end{array}$ & $\mathrm{L}$ \\
\hline \multirow{2}{*}{ Rosaceae } & Pyrus communis Huds. & Naspati & Pear & Fruit edible & $\mathrm{M}, \mathrm{H}$ \\
\hline & Malus pumila Mill. & Seb & Apple & Fruit edible & $\mathrm{M}, \mathrm{H}$ \\
\hline \multirow[t]{2}{*}{ Rutaceae } & Citrus aurantium L. & Narangi & Bitter Orange & Fruit edible & $\mathrm{L}, \mathrm{M}$ \\
\hline & C. sinensis (L.) Osbeck & Malta & Sweet Orange & Fruit edible & $\mathrm{L}, \mathrm{M}$ \\
\hline
\end{tabular}

Abbreviations: L - lower elevation (1000-1500 m, a.m.s.1.), M - middle elevation (1500-2000 m, a.m.s.l.), H - higher elevation (2000-2500 m, a.m.s.1.), m, a.m.s.l. - meters, above mean sea level. 
A greater number of forest tree were found in middle altitude region on agroforestry because more number of population reside in the middle region moreover, mid-altitude represents a transition zone between lower and higher altitude region and thus, the middle altitude region does not possess the climatic extreme of lower and higher (freezing and moist winter) region. The more horticulture species were found in lower altitude region as compared to middle and higher altitude region. Bijalwan and Dobriyal (2016) recorded lesser number of trees in higher altitude and more tree density in lower altitude in different agroforestry systems in upper Yamuna region of Uttarakashi district. Some forest and horticulture tree species were found in two adjacent altitude regions and this can be attributed to the adaptive capacity of the tree, while species such as Pinus roxburghii was found in all the altitude studied, which could be due to species possessing a wide ecological niche.

\section{Conclusion}

The study concludes that forest and horticulture trees provide livelihood support to the villagers by multiple and multifunctional uses. Farmers also deliberately retain these tree species on their farmland for daily domestic and edible purposes.

\section{Conflict of interest statement}

Author declares that there is no conflict of interest.

\section{Acknowledgement}

The author thanks to Director, Indian Institute of
Forest Management, Bhopal for providing support to conduct this study. The author is also thankful to International Papers, Hyderabad (IP-IIFM Paul Brown Centre of Excellence) for providing the financial assistant to conduct the study "Community Livelihood promotion through assessment of Biodiversity and Carbon Sequestration potential in Agroforestry systems along altitude and aspects of Western Himalaya (Project No. IIFM/AB/Ext./Res/Proj./ 2016/03). The author extends thanks to forest department of Uttarkashi and local people of the study area for their help and support during the study.

\section{References}

Bijalwan, A., Dobriyal, M.J.R., 2016. Geometry, distribution and regeneration pattern of trees in agroforestry systems along altitude and aspects in the upper Yamuna region of Uttarakhand Himalaya, India. Appl. Ecol. Environ. Sci. 4(1), 15-25.

Gupta, R.D., Arora, S., 2015. Agroforestry as alternate land use system for sustaining rural livelihoods in Himalayan ecosystem. In: Advances in Soil and Water Resource Management for Food and Livelihood Security in Changing Climate (Eds.: Suraj Bhan and Sanjay Arora). Soil Conservation Society of India, New Delhi. pp.656-669.

Iqbal, K., Hussain, A., Khan, R.A., Pala, N. A., Bhat, J. A., Negi, A.K., 2014. Traditional agroforestry system: A case study from district Chamoli of Garhwal Himalaya. Amer.-Euras. J. Agric. Environ. Sci. 14(9), 905-912.

\section{How to cite this article:}

Bijalwan, A., 2018. Presence of trees under agroforestry systems along altitude in Gangotri valley of Garhwal Himalaya, India. Int. J. Curr. Res. Biosci. Plant Biol. 5(5), 59-64.

doi: https://doi.org/10.20546/ijcrbp.2018.505.010 